\title{
PERFORMANSI KARAKTER SEMANGAT KEBANGSAAN DAN MANAJEMEN PEMBELAJARANNYA PADA SEKOLAH DASAR UMUM DAN KEAGAMAAN
}

\author{
Darmaji $^{1}$, Nurul Ulfatin ${ }^{2}$, Mustiningsih ${ }^{3}$ \\ 1,2,3 Magister Manajemen Pendidikan FIP Universitas Negeri Malang
}

\begin{abstract}
The purpose of this research is to describe the character profile of the national spirit, the learning management design model for the formation of the character of the national spirit, the implementation of learning to form the character of the national spirit, the assessment used to measure the success of the performance of the character building of the national spirit, and the learning outcomes. A qualitative approach with a multi-case research design was used in this study. The locations in this study were SDN Pandanwangi 3 Malang and SD Muhammadiyah 8 KH Mas Mansyur Malang. Data mining used observation, interview, and documentation study techniques, using constant comparative analysis techniques. The results of this study were that the two schools innovated the character values according to the conditions and situations the school had. Learning is carried out by delivering material and giving assignments, and class teachers also integrate the character values of the national spirit through activities outside the classroom. The implementation of learning is integrated with the character values of the national spirit by developing indicators in the lesson plans (RPP). The standard of measurement used by schools is through detailed attitude assessments through RPP. During the process of implementing the national spirit character values that have been carried out by the school, there have been visible changes in the attitudes and behavior of students in a positive direction.
\end{abstract}

Keyword: National Character Performance, Learning Management, Public Schools, Religious Schools

\begin{abstract}
Abstrak: Tujuan dari penelitian ini yakni untuk mendeskripsikan profil karakter semangat kebangsaan, model rancangan manajemen pembelajaran untuk pembentukan karakter semangat kebangsaan, pelaksanaan pembelajaran untuk pembentukan karakter semangat kebangsaan, assesment yang digunakan untuk mengukur keberhasilan performansi pembentukan karakter semangat kebangsaan, dan learning outcomesnya. Pendekatan kualitatif dengan rancangan penelitian multi kasus digunakan dalam penelitian ini. Lokasi dalam penelitian ini yaitu SDN Pandanwangi 3 Malang dan SD Muhammadiyah 8 KH Mas Mansyur Malang. Penggalian data menggunakan teknik observasi, wawancara, dan studi dokumentasi, dengan menggunakan teknik analisis komparatif konstan. Hasil penelitian ini yakni kedua sekolah menginovasikan nilai karakter sesuai dengan kondisi dan situasi yang dimiliki sekolah. Pembelajaran dilakukan dengan penyampaian materi dan pemberian tugas, serta guru kelas juga mengintegrasikan nilai karakter semangat kebangsaan melalui kegiatan di luar kelas. Pelaksanaan pembelajaran diintegrasikan dengan nilai karakter semangat kebangsaan dengan mengembangkan indikator dalam RPP. Standar pengukuran yang digunakan oleh sekolah yaitu melalui penilaian sikap yang sudah dirinci melalui RPP. Selama proses pelaksanaan nilai karakter semangat kebangsaan yang sudah dilakukan sekolah sudah terlihat perubahan yang ada pada sikap dan perilaku peserta didik ke arah yang positif.
\end{abstract}

Kata Kunci: Performansi Karakter Kebangsaan, Manajemen Pembelajaran, Sekolah Umum, Sekolah Keagamaan

\footnotetext{
1 Universitas Negeri Malang, Email: darmajï44回gmail.com

2 Universitas Negeri Malang, Email: nurul.ulfatin.fip国um.ac.id

${ }^{3}$ Universitas Negeri Malang, Email: mustiningsih.fip国um.ac.id
} 


\section{PENDAHULUAN}

Sistem pembelajaran yang diterapkan di sekolah memiliki pengaruh yang besar bagi terbentuknya karakter dan kecerdasan peserta didik. Pembelajaran yang diterima oleh peserta didik menjadi kebutuhan penting untuk membangun masa depan mereka. Oleh karena itu, sekolah sebagai lembaga pendidikan diharapkan mampu untuk mengelola sistem pembelajaran yang baik dan benar. Sesuai dengan fungsi pendidikan nasional yang tertuang pada Undang-Undang No. 20 Tahun 2003 Tentang Sistem Pendidikan Nasional pada Pasal 3 yang berbunyi fungsi pendidikan nasional yaitu untuk mengembangkan kemampuan dan membentuk karakter serta peradaban bangsa yang bermartabat dalam rangka mencerdaskan kehidupan bangsa.

Peserta didik sebagai generasi muda bangsa Indonesia yang dapat meningkatkan martabat dan jati diri bangsa saat ini mengalami krisis karakter yang memprihatinkan. Kepedulian terhadap sesama, toleransi, dan sikap positif lainnya yang semakin tahun seakan hilang, menjadi kekhawatiran tersendiri (Indratmoko et al., 2019). Guna menumbuh kembangkan kembali karakter bangsa Indonesia yang semakin terkikis zaman, maka sekolah, tenaga pendidik dan masyarakat dituntut untuk berperan langsung dalam menangani masalah ini (Juharyanto et al., 2020).

Lemahnya pemahaman tentang landasan filosofis dan historis terbentuknya bangsa ini menjadi suatu bentuk ketidakpedulian warga negara pada bangsanya sendiri. Berbagai persoalan yang terjadi, radikalisasi, perseteruan antar agama menjadi isu penting dan memerlukan upaya solutif (Parker, 2014; Raihani, 2011). Terutama dalam pendidikan yang diharapkan mampu untuk menciptakan generasi yang cerdas, berakhlak, dan demokratis dan berbagai aspek kehidupan memerlukan banyak dukungan untuk mentransformasi pengetahuan (Parker \& Raihani, 2011). Pentingnya upaya memperkuat jati diri bangsa menjadi faktor penting dalam pembangunan bangsa yang bermartabat (Adha et al., 2019).

Sistem tatanan pembelajaran yang baik di sekolah sangat menentukan keberhasilan pembelajaran, penggunaan metode pengajaran yang tepat oleh guru, dan ketersediaan bahan ajar yang cukup untuk menunjang proses pembelajaran tersebut (Sobry, 2012). Dengan pernyataan lain bahwa, pengelolaan pembelajaran dapat memperoleh tujuan belajar sesuai dengan yang diharapkan jika mampu menyeimbangkan antara kemampuan individu, kelengkapan materi atau bahan ajar, dan dukungan serta ketersediaan sarana prasarana yang cukup. Bersamaan dengan adanya sistem pembelajaran yang terkoordinasi dengan baik, pembentukan karakter peserta didik secara langsung dapat diberikan.

Pendidikan karakter mutlak diperlukan dalam pendidikan dasar yang merupakan pintu masuk bagi sesorang untuk dapat melanjutkan perjalanan pada jenjang berikutnya (Hayudiyani et al., 2020; Lo et al., 2019; Maftei \& Holman, 2019). Hal tersebut didukung oleh pernyataan (Samani, 2011) yang memberikan makna bahwa karakter adalah nilai dasar yang dapat membangun diri seseorang karena dampak dari warisan budaya, keturunan maupun faktor lingkungan yang dapat membedakan antara orang satu dengan yang lain serta dilaksanakan dalam sikap dan tingkah laku keseharian. Sebagai sebuah pondasi, maka harus dibangun dengan kuat supaya mampu menahan gempuran, goncangan serta adanya terpaan arus perkembangan dan perubahan jaman. Penanaman nilai karakter semangat kebangsaan menjadi salah satu karakter yang harus dibentuk (Amir, 2013). Nilai semangat kebangsaan yang dimaksud adalah cara berpikir dan bertindak serta keluasan wawasan peserta didik akan pentingnya menjaga martabat bangsa dan negara.

$\begin{array}{ccc}\text { Hasil } & \begin{array}{c}\text { penelitian } \\ \text { bahwa }\end{array} & \begin{array}{c}\text { sebelumnya, } \\ \text { implementasi }\end{array}\end{array}$ 
pendidikan semangat kebangsaan di sekolah yang berlatar belakang Islam dilakukan melalui pembiasaan dan pemberdayaan seluruh warga sekolah di samping fokus utamanya adalah penanaman karakter religius (Priyambodo, 2017), hal ini didukung oleh hasil penelitian (Fadlilatun, 2016) yang menyatakan penanaman karakter semangat kebangsaan di sekolah Islam melalui kedisiplinan, keteladanan guru, pembinaan siswa akan pentingnya menghormati Bendera Merah Putih bukanlah hal syirik. Penumbuhan karakter semangat kebangsaan siswa bisa dimulai dari pemahaman siswa serta guru dan wali murid terhadap landasan filosofis dan historis pembangunan suatu bangsa (Lestyarini, 2012). Karakter semangat kebangsaan dapat melatih kemandirian peserta didik, melalui pengawasan dan motivasi yang diberikan melalui pembelajaran guna mengoptimalkan pelaksanaan penanaman karakter, (Saputri \& Herwin, 2020), dan melalui pembelajaran Pancasila dengan pola yang memprioritaskan peserta didik untuk berfikir kritis dengan kecerdasannya, menyerap nilai dan etika yang dikandung, menerapkan dengan sadar, dan menyebarkannya dengan percaya diri dapat membawa peserta didik menjadi seorang pemimpin yang memiliki ideologi, moral, dan loyalitas (Ahmad, 2018).

Hasil observasi yang dilakukan menunjukkan bahwa SDN Pandanwangi 3 Malang dan SD Muhammadiyah $8 \mathrm{KH}$. Mas Mansyur Malang nilai utama yang dipilih yaitu pembentukan karakter semangat kebangsaan melalui pembiasaan dengan penanaman nilai-nilai agama dalam seluruh kegiatan di sekolah. Hal ini diperkuat dengan visi SDN Pandanwangi 3 Malang yaitu Terwujudnya insan berbudi pekerti, cerdas, terampil, mandiri, berlandaskan iman dan taqwa (IMTAQ), berbudaya dan peduli lingkungan. Hal yang sama juga dibuktikan dengan visi dari SD Muhammadiyah $8 \mathrm{KH}$. Mas Mansyur Malang yaitu Terwujudnya generasi qur'ani, berakhlaqul karimah, unggul dalam prestasi, berintegrasi, berkemajuan, dan berbudaya lingkungan.

Berdasarkan visi tersebut dapat kita simpulkan bahwa dari dua lokasi tersebut memiliki tujuan utama untuk membentuk peserta didik menjadi generasi yang bermanfaat bagi bangsa dan negara dengan berfokus pada nilai keagamaan, berbudaya, dan demokrasi. Terbentuknya visi ini tentunya menjadi kebijakan yang diambil sekolah untuk dijadikan pedoman pelaksanaan kegiatan sekolah. Berdasarkan hal tersebut, maka dirasa menarik untuk meneliti dan mengkaji lebih dalam mengenai performansi karakter semangat kebangsaan dan manajemen pembelajaran pada sekolah dasar umum dan keagamaan. Lokasi yang dipilih ini menurut anggapan peneliti lembaga ini berhasil menjalankan dan membentuk karakter semangat kebangsaan dan manajemen pembelajaran bagi peserta didiknya melalui pembelajaran di dalam kelas dan di luar kelas. Pembelajaran juga dilakukan dengan adanya ekstrakurikuler. Karakter semangat kebangsaan yang dijadikan dasar bagi sekolah untuk membentuk karakter peserta didik agar cinta tanah air dan membangun manusia yang dapat menerapkan nilai-nilai demokrasi, memiliki wawasan nusantara, mewujudkan ketahanan nasional, dan paham atas hak dan kewajiban sebagai warga negara, (Jianfei et al., 2017). Melalui pembelajaran, sekolah dapat menanamkan karakter semangat kebangsaan dengan menyeimbangkan kemampuan individu, kematangan teori dan bahan ajar serta warisan budaya, (Priyambodo, 2017).

\section{METODOLOGI PENELITIAN}

Penelitian ini dilakukan dengan menggunakan pendekatan kualitatif bertujuan untuk mengungkap sebuah petunjuk yang dialami oleh subjek penelitian. Rancangan penelitian yang digunakan yaitu multi kasus, sebab latar penelitian yang berbeda (Ulfatin, 2015). Penelitian ini dilakukan di SDN Pandanwangi 3 Malang dan SD 
Muhammadiyah 8 KH Mas Mansyur Kota Malang. Temuan yang didapat oleh peneliti berupa transkip wawancara, catatan lapangan hasil dari observasi, dan studi dokumen. Hal ini didapatkan berdasarkan wawancara, observasi dan studi dokumentasi. Key informan atau narasumber kunci dalam penelitian ini yaitu kepala SDN Pandanwangi 3 Malang dan Kepala SD Muhammadiyah 8 KH Mas Mansyur Malang. Sumber data lain dari penelitian ini adalah guru kelas, guru mata pelajaran tambahan, siswa, orang tua siswa, kegiatan pembelajaran tambahan, serta dokumen sekolah yang relevan. Proses pengumpulan data dikedua sekolah, terlebih dahulu dilakukan peneliti dengan observasi pendahuluan melalui wawancara tidak terstruktur secara langsung pada kepala sekolah. Selanjutnya, wawancara dan observasi dilakukan secara teratur dan terstruktur sesuai dengan pedoman penelitian. Analisis lintas kasus dalam penelitian ini menggunakan metode perbandingan tetap atau komparatif konstan analisis datanya mencakup reduksi data, kategorisasi data, sintesis, dan diakhiri dengan menyusun sebuah hipotesis kerja. Analisis data lintas kasus dalam penelitian ini melalui membandingkan performansi karakter semangat kebangsaan melalui manajemen pembelajaran pada sekolah dasar umum dan keagamaan secara komparatif konstan. Kegiatan pengecekan keabsahan data dilakukan oleh peneliti untuk memvalidasi apakah data sudah akurat.

\section{HASIL PENELITIAN DAN PEMBAHASAN \\ Profil Karakter Semangat Kebangsaan yang diinginkan oleh Sekolah}

Nilai karakter di SDN Pandanwangi 3 Malang terdiri dari 5 pilar yakni religius, nasionalis, mandiri, gotong royong, dan integritas, demikian juga dengan SD Muhammadiyah $8 \mathrm{KH}$ Mas Mansyur Malang memiliki 5 pilar dalam implementasi Penguatan Pendidikan Karakter (PPK). Sehingga, kedua sekolah tersebut berpedoman pada 5 pilar PPK yang sama. 5 pilar PPK diintegrasikan dalam visi, misi, dan tujuan sekolah. Hal ini disampaikan ketika rapat dan koordinasi seluruh perangkat sekolah. SDN Pandanwangi 3 Malang memfokuskan nilai karakter semangat kebangsaan. Penentuan nilai karakter ini bertujuan untuk menciptakan generasi unggul yang cinta terhadap negaranya. Sedangkan SD Muhammadiyah $8 \mathrm{KH}$ Mas Mansyur Malang memfokuskan nilai religius dan nasionalis. Penentuan nilai karakter ini bertujuan untuk menciptakan generasi penerus bangsa untuk mempertahankan keutuhan bangsa dan menjadi warga negara yang baik.

Nilai karakter semangat kebangsaan yang ingin dibangun oleh sekolah berpengaruh pada seluruh kegiatan sekolah. Pemilihan nilai karakter semangat kebangsaan yang dikembangkan menjadi pembeda dengan sekolah lain. Nilai karakter semangat kebangsaan dapat diintegrasikan dalam visi dan misi sekolah dan telah disepakati bersama. Sehingga nilai karakter ini lah yang diusung oleh sekolah untuk membentuk karakter individu sebagai salah satu langkah yang dilakukan oleh sekolah guna menciptakan karakter semangat kebangsaan peserta didik.

Hal tersebut yang dilakukan oleh SDN Pandanwangi 3 Malang dan SD Muhammadiyah $8 \mathrm{KH}$ Mas Mansyur Malang, kedua sekolah memilih dan melaksanakan nilai karakter semangat kebangsaan yang diyakini, dilaksanakan, dan dinternalisasikan pada seluruh kegiatan sekolah. Kedua sekolah juga menginovasikan nilai karakter sesuai dengan kondisi dan situasi yang dimiliki sekolah. Nilai karakter semangat kebangsaan tersebut oleh sekolah dikembangkan berdasarkan Peraturan Presiden Republik Indonesia Nomor 87 Tahun 2017 Tentang Pendidikan Karakter (PPK) yang merupakan tanggung jawab dari lembaga pendidikan yang dalam pelaksanaannya harus disesuaikan dengan 
visi dan misi sekolah yang telah disepakati bersama.

Nilai karakter semangat kebangsaan juga menjadi salah satu karakter yang dikembangkan oleh Kementerian Pendidikan dan Kebudayaan Republik Indonesia sebagai berikut religius, jujur, toleransi disiplin, kerja keras, kreatif, mandiri, demokratis, rasa ingin tahu, semangat kebangsaan, cinta tanah air, menghargai prestasi, bersahabat/komunikatif, cinta damai, gemar membaca, peduli lingkungan, peduli sosial, dan tanggung jawab (Wibowo, 2013). Karakter semangat kebangsaan diinovasikan oleh sekolah sebagai tujuan lembaga untuk mendidik moral, budi pekerti, dan nilai kehidupan peserta didik.

Melalui nilai karakter semangat kebangsaan ini diharapkan peserta didik dapat memiliki wawasan lebih dan rasa peduli pada bangsanya sendiri. Hal ini sesuai dengan pendapat dari Lestyarini (2012), hal yang paling mendasar dalam konsep karakter semangat kebangsaan ini yaitu perjuangan untuk menghadapi diri sendiri, hasrat untuk menjunjung nilai diri, kemauan untuk berdampingan dengan sesama sebagai suatu persatuan penduduk atau warga sekolah. Artinya, hal yang perlu diperangi dan ditumbuhkan terlebih dahulu adalah kesadaran peserta didik untuk mampu menerima dirinya sendiri sebagai individu yang memiliki nilai dan martabat untuk di bela. Nilai tersebut perlu diciptakan dalam diri peserta didik guna menjalani kehidupan berbangsa dan bernegara. Harapanya, peserta didik memiliki jiwa patriotisme, toleransi, jujur, dan beriman pada sang pencipta.

Pentingnya nilai karakter semangat kebangsaan dimulai dari kesadaran tiap individu untuk membawa jati diri mereka pada zaman dan eksistensinya yang harus disikapi dengan membangun peradaban bangsa yang maju dan bermartabat. Selfrespect yang dikemukakan oleh (Soedjatmoko, 2009) yaitu harga diri yang harus dimiliki setiap individu dengan menganggap bahwa masing-masing orang memiliki kreatifitas dan inovasi untuk mengikuti arus perkambangan zaman dan memperluas wawasan sosial untuk pembangunan bangsa yang mandiri dan bermartabat. Pentingnya wawasan ilmu pengetahuan sosial manusia sebagai salah satu konstruk untuk melibatkan peserta didik lebih paham mengenai fenomena lingkungan sekitar (Borsheim et al., 2008). Terdapat beberapa indikator karakter semangat kebangsaan menurut Kementerian Pendidikan Nasional (2010) yaitu sebagai berikut:

Tabel 1 Indikator Karakter Semangat Kebangsaan

\begin{tabular}{|c|c|c|}
\hline Nilai & Indikator Sekolah & $\begin{array}{l}\text { Indikator } \\
\text { Kelas }\end{array}$ \\
\hline \multirow[t]{5}{*}{$\begin{array}{l}\text { Semangat } \\
\text { Kebangsaan }\end{array}$} & $\begin{array}{l}\text { Melakukan upacara } \\
\text { rutin sekolah }\end{array}$ & \multirow{3}{*}{$\begin{array}{l}\text { Bekerjasama } \\
\text { dengan teman } \\
\text { sekelas yang } \\
\text { berbeda suku, } \\
\text { etnis, status } \\
\text { sosial }\end{array}$} \\
\hline & $\begin{array}{l}\text { Melakukan upacara } \\
\text { hari-hari besar nasional }\end{array}$ & \\
\hline & $\begin{array}{l}\text { Menyelenggarakan } \\
\text { peringatan hari } \\
\text { kepahlawanan nasional }\end{array}$ & \\
\hline & $\begin{array}{l}\text { Memiliki program } \\
\text { melakukan kunjungan } \\
\text { ke tempat bersejarah }\end{array}$ & \multirow[t]{2}{*}{$\begin{array}{l}\text { Mendiskusikan } \\
\text { hari-hari besar } \\
\text { nasional }\end{array}$} \\
\hline & $\begin{array}{l}\text { Mengikuti lomba pada } \\
\text { hari besar nasional }\end{array}$ & \\
\hline
\end{tabular}

Indikator-indikator tersebut di atas dapat dikembangkan lagi oleh sekolah dan disesuaikan dengan situasi dan kondisi sekolah. Definisi kegiatan beserta poin pendukung dan skala atau tolak ukur keberhasilan juga ditentukan oleh sekolah tersebut. Harapan sekolah terhadap nilai karakter semangat kebangsaan yang dikembangkan dan diinovasikan ini dapat mengacu pada nilai dan indikator tersebut. Sehingga dalam pelaksanaannya akan lebih terarah dan ada target serta sasaran.

Berdasarkan data yang diperoleh dari kedua sekolah diketahui bahwa nilai karakter semangat kebangsaan dipilih sebagai karakter utama yang dikembangkan dan dijunjung tinggi. Pengembangan pendidikan karakter semangat kebangsaan dilakukan di lembaga pendidikan yang terkandung pendidikan moral, budi pekerti, karakter dan nilai kehidupan. Pendidikan karakter sejatinya yaitu meningkatkan kualitas kehidupan peserta didik (Pane \& Patriana, 2016). Dengan adanya pendidikan 
karakter, sekolah dapat membekali peserta didik sehingga mereka siap untuk memberikan kontribusi pada lingkungan masyarakat. Perencanaan pembelajaran dan program unggulan juga dilakukan untuk mendukung terwujudnya visi dan misi sekolah yang telah disepakati bersama. Mengenai integrasi pendidikan karakter ke dalam pembelajaran di sekolah, konsep dasar dan alur yang sistematis pengembangan pendidikan karakter harus difokuskan. Dalam mengimplementasikan pendidikan karakter secara komprehensif ada empat macam cara yaitu inkulkasi, keteladanan, fasilitasi, dan pengembangan keterampilan (Zuchdi, 2009).

\section{Model Rancangan Manajemen Pembelajaran untuk Pembentukan Karakter Semangat Kebangsaan Peserta Didik}

Model manajemen pembelajaran pembentukan karakter SDN Pandanwangi 3 Malang diintegrasikan melalui Rencana Pelaksanaan Pembelajaran (RPP) dan silabus, sedangkan SD Muhammadiyah 8 KH Mas Mansyur Malang diintegrasikan melalui RPP dan silabus serta merinci Kompetensi Inti (KI) dan Kompetensi Dasar (KD) sesuai dengan tema. Kegiatan ekstrakurikuler juga diintegrasikan dengan nilai karakter semangat kebangsaan seperti pramuka, drumband, dan tari tradisional. SD Muhammadiyah $8 \mathrm{KH}$ Mas Mansyur Malang mengintegrasikan dalam kegiatan ekstrakurikuler seperti pramuka, tapak suci, panahan, dan tari tradisional. Selain itu, penyelenggaraan pembentukan karakter semangat kebangsaan di kedua sekolah melalui Peringatan Hari Besar Nasional (PHBN) seperti Upacara bendera, Perayaan Hari Kemerdekaan 17 Agustus, Hari Kesaktian Pancasila, Hari Sumpah Pemuda, dan Hari Kartini. Terdapat pula pembiasaan untuk membentuk karakter semangat kebangsaan di SDN Pandanwangi 3 Malang seperti kegiatan cinta lingkungan, salat berjamaah, kantin kejujuran, budaya salim, dan budaya Literasi. SD Muhammadiyah $8 \mathrm{KH}$ Mas Mansyur
Malang dalam pembiasaannya melalui piket guru, menyayikan lagu Indonesia Raya dan melafalkan Pancasila sebelum memulai pembelajaran, salat berjamaah, budaya salim, dan jumat bersih.

Kedua sekolah menciptakan model pembelajaran dengan model integrasi. Dengan pembelajaran guru dapat mengintegrasikan nilai karakter semangat kebangsaan pada setiap kegiatan peserta didik dalam mata pelajaran. Sebelum menerapkannya dalam pembelajaran, tentunya perangkat sekolah menyusun rancangan pembelajaran. Pembelajaran adalah proses interaksi guna membantu peserta didik mendapatkan pengetahuan dan pengalaman belajar dengan baik (Fathoni, 2015). Kedua sekolah mengintegrasikan nilai karakter semangat kebangsaan di dalam dan di luar kelas. Hal tersebut dilakukan dengan menyusun perangkat sekolah mulai dari RPP hingga evaluasi pembelajaran.

Pembelajaran di sekolah dilaksanakan melalui manajemen pembelajaran yang efektif dan efisien maka sekolah dapat mencapai tujuan dan sasaran pembelajaran yang diinginkan. Manajemen merupakan tatanan sistem atau strategi yang memberdayakan orang lain untuk melaksanakan aktifitas dan kegiatan organisasi yang terarah untuk mencapai tujuan tertentu (Lawrence \& Lee, 2010). Wujud dari manajemen pembelajaran adalah munculnya strategi pembelajaran, model pembelajaran, dan metode pembelajaran yang menjadi sarana untuk mencapai tujuan pembelajaran.

Secara rinci kedua sekolah mengintegrasikan nilai karakter semangat kebangsaan dalam prota dan promes sekolah dan dideskripsikan lagi melalui RPP. Melalui pembelajaran guru dapat menambahkan dan mengembangkan indikator dalam RPP, yang kemudian dijabarkan lagi dan diinovasikan oleh guru kelas sehingga pembelajaran nilai karakter peduli lingkungan dikemas dengan menarik. Sebagaimana yang dikemukakan oleh (Sarah, 2015) yaitu dalam sisi internal, 
pengembangan strategi pendidikan karakter peduli lingkungan dapat dilakukan dengan mengintegrasikan nilai karakter pada mata pelajaran melalui perencanaan kurikulum yang menghasilkan Silabus dan RPP yang berisi komponen perangkat pembelajaran dari rencana pembelajaran yang mencakup standar kompetensi, kompetensi dasar, indikator, penilaian, alokasi waktu, dan sumber belajar.

Melalui pengintegrasian nilai karakter semangat kebangsaan dalam pembelajaran dalam kelas dapat mendukung program secara menyeluruh. Kegiatan pembelajaran dilakukan sekolah dengan penyampaian materi dan pemberian tugas pada peserta didik. Selain itu, guru kelas juga dapat mengintegrasikan nilai karakter semangat kebangsaan melalui kegiatan di luar kelas. Kegiatan tersebut dibuktikan dengan adanya ekstrakurikuler tari tradisional, pramuka, bela diri, kunjungan ke Museum Brawijaya, dan lainlain. Adapun kegiatan literasi yang dilakukan di setiap kelas untuk menunjang keberhasilan pembelajaran dengan adanya sudut baca di setiap kelas dan di ruang guru. Seperti yang dipaparkan oleh Lusty \& Maisyaroh (2015) yaitu pendidikan karakter dapat diintegrasikan dalam materi pembelajaran yang ada di sekolah, prosesnya dapat melalui penyampaian materi di depan kelas (ceramah) dapat juga melalui praktek langsung di lapangan.

Pembelajaran dalam kelas dilakukan guru sesuai dengan RPP dengan melakukan kegiatan pendahuluan, kegiatan pendahuluan ini dapat dilakukan guru dengan memberikan pertanyaanpertanyaan sederhana dikaitkan dengan materi yang diajarkan. Kegiatan ini bertujuan untuk mempersiapkan psikis dan fisik peserta didik agar siap mengikuti pembelajaran (Gunawan, 2012). Model pembelajaran di kedua sekolah juga dilakukan di luar kelas dengan mengikuti dan merayakan PHBN yang sudah direncanakan di awal tahun ajaran. Secara terpisah, model pembelajaran merupakan seluruh aktifitas perencanaan dan langkah- langkah selanjutnya untuk proses kegiatan penyampaian mata pelajaran. Strategi pembelajaran merupakan cara praktis yang dapat dilakukan oleh sekolah atau guru dalam mentransfer ilmu pengetahuan pada peserta didik yang disesuaikan dengan bahan ajar dan individu peseta didik. Metode pembelajaran adalah teknik pengajaran yang dipilih untuk mempermudah penyampaian nilai dan mata pelajaran yang diinginkan (Fadlillah, 2012).

Dalam pembelajaran yang dilakukan tentunya melibatkan banyak pihak antara lain pihak internal dan eksternal sekolah. Pihak internal sekolah meliputi tenaga pendidik(guru), tenaga kependidikan (staf), dan kepala sekolah sebagai leader dan manajer. Pihak eksternal wali murid, komite sekolah, stake holder, masyarakat sekitar sekolah. Pentingnya dukungan penuh dari seluruh perangkat sekolah dan partisipasi wali murid dan komite sekolah dalam menyukseskan program sekolah karena dibutuhkan sinergitas antar pihak sekolah dan orang tua (Arifin et al., 2018; Ulfatin et al., 2019). Sebaik apapun program sekolah tanpa adanya dukungan orang tua maka jalanya program tidak akan lancar dan hasilnya juga kurang maksimal. Jadi dukungan orang tua di rumah juga memiliki peran yang sangat besar dalam pada setiap program sekolah. Keikutsertaan masyarakat dalam bidang politik dengan mengupayakan untuk berperan aktif dalam pembangunan lingkungan sekitarnya merupakan upaya bela negara (Febriyanti, 2017).

Keikutsertaan peseta didik dalam PHBN atau perayaan nasionalis lainnya juga sangat penting dilakukan, peseta didik merasa senang dan dihargai dapat berpartisipasi dalam program sekolah. Melalui kegiatan ekstrakurikuler dan program unggulan sekolah yang juga dibentuknya kader-kader menjadi salah satu upaya strategis sekolah dalam mengoptimalkan dukungan dan partisipasi untuk mewujudkan visi misi sekolah yang 
telah disepakati bersama. Pembelajaran karater berbasis peserta didik merupakan pembelajaran yang yang berfokus pada karakter individu tiap peserta didik yang meliputi tiga ranah yaitu kognitif, afektif, dan psikomotorik atau secara singkat pembelajaran student centered (Zahroh, 2016).

Berdasarkan data yang diperoleh dari kedua sekolah diketahui bahwa pengintegrasian model pembelajaran pendidikan karakter dengan pembelajaran memerlukan waktu yang cukup dan kegiatan yang dilakukan berulang-ulang. Mengembangkan nilai karakter dalam pembelajaran dengan memahami dan menerapkan teori sehingga peserta didik paham sejarah dan ilmu pengetahuan dasar mengenai kenegaraan, (Rokhman et al., 2014). Memadukan nilai-nilai karakter yang ingin dikembangkan dan disisipkan pada setiap mata pelajaran yang diajarkan di kelas. Kegiatan di luar sekolah dapat dilakukan dengan mengajak peserta didik untuk keluar kelas dan melakukan diskusi bersama mengenai kegiatan yang dilakukan misalnya bakti sosial, melakukan amal, berkunjung ke panti asuhan dan lain-lain. Menggabungkan kegiatan di dalam sekolah dan di luar sekolah. sekolah atau guru menjalin kerjasama dengan pihak luar untuk melakukan kegiatan penanaman nilai karakter peserta didik melalui berbagai macam kegiatan menarik. Pembiasaan dapat dilakukan oleh guru disetiap pembelajaran yang dilakukan. Sehingga baik di dalam kelas ataupun diluar kelas peserta didik mendapat pengalaman belajar yang diinginkan.

\section{Pelaksanaan Pembelajaran untuk Pembentukan Karakter Semangat Kebangsaan Peserta Didik}

Pelaksanaan pembelajaran untuk pembentukan karakter semangat kebangsaan di SDN Pandanwangi 3 dan SD Muhammadiyah $8 \mathrm{KH}$ Mas Mansyur Malang melalui pengembangan sikap semangat kebangsaan melalui mata pelajaran. Inovasi pembelajaran dengan praktek dan simulasi dilakukan SDN Pandanwangi 3 Malang untuk membentuk karakter semangat kebangsaan, dalam implementasinya alur pembelajaran sesuai dengan KI/KD yang sudah ditetapkan. Sama halnya dengan SD Muhammadiyah 8 $\mathrm{KH}$ Mas Mansyur Malang untuk membentuk karakter semangat kebangsaan melalui pembelajaran sesuai dengan standar, hal ini dalam implementasinya juga menetapkan alur pembelajaran sesuai dengan KI/KD yang sudah ditetapkan. Program unggulan di SDN Pandanwangi 3 Malang yakni outing class, terdapat pula slogan dan pajangan yang ada di seluruh sudut sekolah (Mural, banner, papan peringatan). Sedangkan, SD Muhammadiyah $8 \mathrm{KH}$ Mas Mansyur Malang yakni tahfidz Quran dan outing class, terdapat slogan dan pajangan yang ada di seluruh sudut sekolah (banner, papan peringatan yang berisi ayat al-qur'an).

Pelaksanaan pembelajaran yang dilakukan oleh sekolah yang diintegrasikan dengan nilai karakter semangat kebangsaan dengan mengembangkan indikator dalam RPP. Dengan merinci Kompetensi Inti (KI) dan Kompetensi Dasar (KD) yang harus dikuasai oleh peserta didik. Sebagaimana pendapat dari Rokhman, Hum, \& Syaifudin (2014), pelaksanaan pembelajaran salah satunya integrasi model atau biasanya disebut dengan model terpadu. Model terpadu yaitu memadukan nilai-nilai karakter yang ingin dikembangkan dan disisipkan pada setiap mata pelajaran yang diajarkan di kelas. Hal ini dapat dilakukan secara terus menerus selama proses pembelajaran berlangsung sehingga mendapat hasil yang diinginkan.

Kegiatan penanaman nilai karakter semangat kebangsaan memiliki serangkaian kegiatan di luar kelas ataupun di luar sekolah. Kegiatan tersebut disebut kegiatan outing class yang memiliki kegiatan yang berbeda-beda setiap kelasnya. Hal tersebut dilakukan untuk memberikan pengalaman belajar bagi peserta didik. sehingga peserta didik tidak hanya belajar dalam kelas namun juga 
memiliki pengalaman langsung tentang bangsa dan tanah airnya. Sebelumnya, kegiatan keluar kelas ini juga memiliki tahapan, dengan diawali dengan pembuatan proposal terlebih dahulu yang kemudian ditujukan pada kepala sekolah. Setelah kepala sekolah menyetujui, maka kegiatan tersebut dapat dilakukan. Sebagaimana pendapat dari (Rokhman et al., 2014), salah satu pembelajaran yang mampu untuk mendukung keberhasilan dalam pelaksanaan pendidikan karakter yaitu out of school time yang artinya model pembelajaran pendidikan karakter yang dilakukan diluar jam sekolah reguler, model ini berfokus pada kegiatan di luar sekolah. Kegiatan ini dapat dilakukan dengan mengajak peserta didik untuk keluar kelas dan melakukan diskusi bersama mengenai kegiatan yang dilakukan misalnya bakti sosial, melakukan amal, berkunjung ke panti asuhan dan lain-lain.

Kedua sekolah juga melakukan pembiasaan dengan merayakan PHBN dan perayaan nasionalis lainnya dengan melibatkan peserta didik sebagai peran utamanya. Sebagaimana pendapat dari (Asmani, 2012), pelaksanaan pendidikan karakter dalam sekolah memiliki empat jenis yaitu (1) pendidikan karakter yang berfokus pada nilai religi (moral); (2) pendidikan karakter berfokus nilai kultur dan budaya bangsa dengan tidak meninggalkan sejarah bangsa (Pancasila, pahlawan, dan Bahasa); (3) pendidikan berlandaskan lingkungan sekitar; dan (4) pendidikan karakter yang berfokus pada kompetensi individu yang mencakup perilaku, potensi, dan ketrampilan. Pembelajaran karakter ini menempatkan peserta didik sebagai subjek utama yang memiliki kemampuan belajar dan potensi diri untuk dikembangkan sehingga peserta didik tumbuh menjadi manusia berkarakter.

Dalam pelaksanaan pendidikan karakter semangat kebangsaan, tidak dapat terlepas dari faktor pendukung dan penghambat. Faktor pendukung dan penghambat dalam menanamkan nilai-nilai karakter kepada peserta didik yang ada di sekolah, tentunya dapat berasal dari faktor internal ataupun eksternal sekolah. Faktor pendukung dari kedua sekolah yaitu guru dan wali murid. Sebagaimana yang dikemukakan oleh (Bafadal, 2015) yaitu pelibatan wali murid perlu diadakan jalur strategis yaitu (1) integrasi materi pendidikan budi pekerti ke dalam tema pembelajaran di sekolah; (2) integrasi melalui kegiatan ekstrakurikuler; (3) melalui pembiasaan dan pembudayaan setiap hari di sekolah; dan (4) melalui pembiasaan di rumah yang diselaraskan dengan pembiasaan di sekolah. Dukungan dari banyak pihak inilah yang menjadi salah satu faktor pendukung optimalnya pelaksanaan karakter semangat kebangsaan.

Faktor penghambat dalam pelaksanaan program pun tak dapat dipisahkan, faktor penghambat dari kedua sekolah juga. Masalah-masalah timbul seiring berjalannya program. Perbedaan fasilitas yang ada di sekolah dan di rumah serta perbedaan pembiasaan juga dapat menjadi penghambat sebagaimana yang diungkapkan (Kalimantara, 2016) juga menyebutkan bahwa adanya perbedaan pembiasaan antara pembiasaan di sekolah dan di rumah menjadikan peserta didik tidak melaksanakan pembiasaan yang dilakukan di sekolah ketika berada di rumah. (Andriani, 2014) juga menyampaikan hambatan pelaksanaan pendidikan karakter dalam penelitiannya yaitu meliputi (1) sikap orang tua yang tidak peduli dengan anaknya; (2) minimnya biaya yang dimiliki; (3) peserta didik pasif dalam pembelajaran; dan (4) suasana pembelajaran yang tidak kondusif).

Berdasarkan temuan yang diperoleh peneliti dari kedua sekolah diketahui bahwa kedua sekolah mengembangkan pembelajaran dengan menyisipkan $\mathrm{KI} / \mathrm{KD}$ dengan indikator nilai karakter semangat kebangsaan. Guru dengan mulai menyusun silabus, RPP, dan bahan ajar lain dengan memuat kegiatan belajar yang berkarakter (Zulaikha, 2014). Pembelajaran yang yang berfokus pada karakter individu tiap peserta 
didik yang meliputi tiga ranah yaitu kognitif, afektif, dan psikomotorik atau secara singkat pembelajaran student centered (Zahroh, 2016). Guru dapat memberikan kesempatan peserta didik untuk mengungkapkan pendapat secara lisan ataupun tertulis. Kemudian dapat dilanjutkan dengan kegiatan penyajian hasil laporan akhir sesuai dengan topik pembahasan (Gunawan, 2012).

\section{Assesment yang digunakan untuk Mengukur Keberhasilan Performansi Pembentukan Karakter Semangat Kebangsaan Peserta Didik}

Assessment untuk mengukur

keberhasilan pembentukan karakter semnagat kebangsaan dilakukan pihak di SDN Pandanwangi 3 Malang dengan penilaian sikap mandiri sesuai dengan standar RPP, baik di dalam atau luar kelas. Berbeda halnya dengan SD Muhammadiyah $8 \mathrm{KH}$ Mas Mansyur Malang, pihak sekolah melakukan penilaian sikap mandiri sesuai standar RPP di dalam dan luar kelas (KI-1, KI-2, KI-3). Untuk evaluasi kedua sekolah melakukan evaluasi secara langsung dan rutin atau terjadwal. Penilaian sikap sesuai dengan indikator nilai karakter semangat kebangsaan dilakukan oleh SDN Pandanwangi 3 Malang, sedangkan SD Muhammadiyah $8 \mathrm{KH}$ Mas Mansyur Malang melalui penilaian sikap melalui rewards and punishment (sistem poin). Berdasarkan penilai tersebut kedua sekolah memperoleh nilai yakni ketercapaian tujuan pembelajaran ditunjukan dengan hasil akhir sikap dan pengetahuan peserta didik.

Proses pelaksanaan karakter semangat kebangsaan di sekolah tentunya terdapat hambatan dan permasalahan yang muncul. Permasalahan tersebut mampu diatasi oleh sekolah dengan melakukan evaluasi secara rutin. Kedua sekolah memiliki perencanaan dan persiapan untuk mengatasi hal tersebut. Standar pengukuran yang digunakan oleh sekolah yaitu melalui penilaian sikap yang sudah tertuang dan dirinci melalui RPP. Penilaian sikap ini tentunya berbeda pada setiap jenjang walaupun tujuannya sama. Dengan merinci penilaian dalam setiap sub tema karena dalam setiap tema mengintegrasikan nilai karakter semangat kebangsaan. Pengetahuan peserta didik mengenal lambang-lambang negara, tokoh pahlawan, dan sikap saling menghargai dan tolong menolong juga beberapa unsur yang menjadi penilaian peserta didik. Penilaian ini tidak hanya mencakup penilaian pembelajaran di dalam kelas namun juga di luar kelas. Proses assesment atau evaluasi yang dilakukan oleh sekolah memiliki tahapan-tahapan rutin namun tetap berfokus pada penilaian pada sikap peserta didik. Sebagaimana pendapat dari (Kurniadin \& Machali, 2012) yaitu pengawasan merupakan tindakan untuk mengukur dan mengamati kegiatan yang nantinya akan dibandingkan dengan standar yang sudah ditetapkan dalam perencanaan sebelumnya.

Assesment yang dilakukan oleh guru atau juga sekolah memiliki hasil yang terlihat. Perilaku peserta didik mulai menunjukan banyak perubahan. Evaluasi juga dapat dilakukan secara berkala bisa satu bulan sekali atau setiap akhir semester seperti yang dilakukan oleh kedua sekolah. Sebagaimana menurut Hamalik (2009) proses evaluasi terdiri dari beberapa tahap yaitu (1) evaluasi internal; (2) rancangan revisi; (3) pendapat ahli; (4) komentar yang dapat dipercaya; dan (5) model kurikulum. Tentunya tidak semuanya peserta didik berubah sikapnya sesuai dengan harapan sekolah. Namun setidaknya, dengan peserta didik menghargai teman dan guru, memiliki sikap toleransi dan memahami lambanglambang negara merupakan kemajuan yang bagus.

Berdasarkan temuan yang diperoleh oleh peneliti dari kedua kasus diketahui bahwa assesment dilakukan melalui evaluasi rutin dan terjadwal serta dapat dilakukan secara langsung saat pembelajaran atau kegiatan sekolah. Kegiatan evaluasi juga dilakukan melalui supervisi dari kepala sekolah ke guru dan 
guru ke peserta didik (Mustiningsih, 2017). Proses evaluasi yang tepat membawa dampak positif bagi organisasi atau lembaga pendidikan, dengan mengidentifikasi permasalahan dan dikomunikasikan mengenai faktor penghambat dan segala penyebabnya guna ditindaklanjuti bersama. Evaluasi dapat mencegah organisasi mengambil keputusan yang salah dan membantu organisasi untuk mengantisipasi tantangan dan resiko perubahan lingkungan (Dubihlela \& Sandada, 2014). Instrumen evaluasi umumnya berdasar pada penilaian sikap dari KI/KD dalam RPP.

\section{Learning Outcomes dari Performansi Pembentukan Karakter Semangat Kebangsaan Peserta Didik}

Learning outcomes pembentukan karakter semangat kebangsaan di kedua sekolah melalui penilaian perubahan sikap dan perilaku peserta didik ke arah positif daripada sebelum adanya pembiasaan, seperti tidak saling mengejek sesama teman, tidak malas untuk upacara, saat upacara bersikap diam dan khidmat. Berdasarkan hal tersebut peserta didik di SDN Pandanwangi 3 Malang lebih menghargai dan santun terhadap guru, toleransi sesama teman, khidmat saat pelaksanaan upacara, dan jujur. Tidak hanya itu, sekolah juga dapat melihat perubahan gestur dan mimik wajah (semangat, senang, bangga). Berbeda halnya dengan SD Muhammadiyah $8 \mathrm{KH}$ Mas Mansyur Malang, peserta didik didik lebih tertib, disiplin, menghargai dan santun terhadap guru, toleransi sesama teman, dan jujur. Hal ini juga dapat dinilai dari perubahan gestur dan mimik wajah (semangat, antusias, bangga), ditunjukan dengan sikap antusias saat tiba giliran melaksanakan upacara, semangat dalam menyanyikan lagu wajib, bangga ditunjukan dengan mengepalkan tangan dengan tenaga penuh.

Selama proses pelaksanaan nilai karakter semangat kebangsaan yang sudah dilakukan sekolah tentunya sudah terlihat perubahan yang ada pada sikap dan perilaku peserta didik. Perubahan sikap dan perilaku peserta didik sudah menunjukan ke arah yang lebih positif dan sesuai dengan harapan sekolah. Peserta didik dapat membawa dirinya untuk lebih menghargai dan menghayati tujuan diadakannya upacara bendera. Peserta didik sudah lebih santun dan hormat kepada guru, juga tidak saling mengejek sesama teman. Terdapat enam bentuk poin penting karakter semangat kebangsaan menurut (Febriyanti, 2017) yaitu sebagai berikut:

Tabel 2 Fokus Karakter Semangat Kebangsaan

\begin{tabular}{|c|c|}
\hline $\begin{array}{l}\text { Poin Karakter Semangat } \\
\text { Kebangsaan }\end{array}$ & Definisi \\
\hline $\begin{array}{l}\text { Nasionalisme } \\
\text { Kewarganegaraan }\end{array}$ & $\begin{array}{l}\text { Semangat } \\
\text { kebangsaan yang } \\
\text { memfokuskan } \\
\text { pada kebenaran } \\
\text { politik dari budaya } \\
\text { asal atau etnis } \\
\text { dalam masyarakat }\end{array}$ \\
\hline Nasionalisme Etnis & $\begin{array}{l}\text { Fokus pada } \\
\text { kebenaran politik } \\
\text { dari budaya asal }\end{array}$ \\
\hline $\begin{array}{l}\text { Nasionalisme } \\
\text { Romantik/Organik/Identitas }\end{array}$ & $\begin{array}{lr}\text { Fokus } & \text { pada } \\
\text { kebenaran } & \text { politik } \\
\text { secara } & \text { murni } \\
\text { (organik) hasil dari } \\
\text { bangsa dengan } \\
\text { semangat }\end{array}$ \\
\hline Nasionalisme Budaya & $\begin{array}{lr}\text { Fokus } & \text { pada } \\
\text { kebenaran } & \text { politik } \\
\text { dari } & \text { budaya } \\
\text { bersama } & \text { bukan } \\
\text { yang } & \text { bersifat } \\
\text { keturunan seperti } & \text { warna kulit, ras, } \\
\text { dan sebagainya }\end{array}$ \\
\hline Nasionalisme Kenegaraan & \begin{tabular}{ll}
\multicolumn{2}{l}{ Variasi } \\
nasionalisme \\
kewarganegaraan \\
sehingga memberi \\
kekuatan rasa \\
nasionalistik \\
dengan keutamaan \\
mengatasi hak \\
universal dan \\
kebebasan
\end{tabular} \\
\hline Nasionalisme Agama & $\begin{array}{lr}\text { Fokus } & \text { pada } \\
\text { legitimasi politik } \\
\text { dari persamaan } \\
\text { agama }\end{array}$ \\
\hline
\end{tabular}


Perubahan dan sikap peserta didik yang menunjukan perubahan, peserta didik juga memiliki ekspresi sendiri untuk menunjukan bahwa mereka bangga dan cinta terhadap bangsa dan negaranya. Untuk kelas rendah mereka sudah mulai hafal dan memahami sila dalam Pancasila juga mengamalkanya di kehidupan mereka sehari-hari. Hal yang paling mendasar dalam konsep karakter semangat kebangsaan ini yaitu perjuangan untuk menghadapi diri sendiri, hasrat untuk menjunjung nilai diri, kemauan untuk berdampingan dengan sesama sebagai suatu persatuan penduduk atau warga sekolah (Lestyarini, 2012).

Perubahan-perubahan tersebut juga memperlihatkan kemampuan peserta didik dalam menyikapi adanya perbedaan. Peserta didik memiliki sikap toleransi antara sesama teman dalam berbagai hal. Luasnya pengetahuan peserta didik tentang keanekaragaman budaya di Indonesia menyebabkan peserta didik memiliki jiwa toleransi tinggi terhadap teman-temanya. Peserta didik sudah lebih santun dan hormat kepada guru, juga tidak saling mengejek sesama teman. Hal tersebut dicerminkan dengan adanya perbedaan suku, dan ras, strata ekonomi orang tua yang ada di sekolah peseta didik tidak melakukan bullying (Novitawati et al., 2019). Pentingnya wawasan ilmu pengetahuan sosial manusia sebagai salah satu konstruk untuk melibatkan peserta didik lebih paham mengenai fenomena lingkungan sekitar (Borsheim et al., 2008). Permasalahan pun muncul seiring dengan pemahaman ilmu sosial tersebut, banyaknya aliran, tingkatan, dan kelompok yang ada di masyarakat juga menjadi faktor pendukung menurunya moral masyarakat.

Berdasarkan temuan yang diperoleh dari kedua sekolah diketahui bahwa tidak semua peserta didik berubah secara drastis, namun lambat laun sekolah terus menerus memperbaiki sehingga seluruh peserta didik memiliki karakter semangat kebangsaan untuk melindungi, menjaga ketahanan, dan kedamaian bangsa dan negaranya singkatnya peserta didik menjadi warga negara yang baik. Hal tersebut dapat terlihat dari adanya simbol negara dengan adanya bendera kebangsaan, budaya penduduk, dan adanya perbedaan agama, ras, dan suku, (Lestyarini, 2012). Ikatan nilai kebangsaan yang saling berkaitan menjadi satu kesatuan yang kuat untuk bersama-sama menjaga kedaulatan bangsa. Membentuk dan menciptakan sudut pandang dan pola pikiran peserta didik dengan nilai ketulusan, percaya diri, dan toleransi (Ahmad, 2018). Pengembangan nilai atau karakter yang dibawa oleh masing-masing peserta didik dalam sikap dan perilaku selama di sekolah (mulai masuk hingga lulus). Menyelaraskan kegiatan dan perilaku peserta didik di sekolah dengan di rumah (lingkungan tempat tinggal). Menggabungkan kebiasaan-kebiasaan berdasar pada tingkatan kelas yang bertujuan pada perkembangan pola pikir peserta didik. Dilaksanakan melalui pembelajaran maka dampak yang timbul yaitu terbangunnya hubungan antara sekolah dan masyarakat utamanya wali murid (Ash-shidiqqi, 2018; Shidiq \& Raharjo, 2018).

\section{KESIMPULAN}

Karakter semangat kebangsaan menjadi nilai yang dibangun dan dijunjung tinggi oleh sekolah. Hal tersebut yang dilakukan oleh sekolah umum dan sekolah keagamaan, kedua sekolah memilih dan melaksanakan nilai karakter semangat kebangsaan yang diyakini, dilaksanakan, dan dinternalisasikan pada seluruh kegiatan pembelajaran di sekolah.

Berdasarkan hasil dan pembahasan, simpulan penelitian ini yakni, kedua sekolah menginovasikan nilai karakter sesuai dengan kondisi dan situasi yang dimiliki sekolah. Kegiatan pembelajaran dilakukan dengan penyampaian materi dan pemberian tugas pada peserta didik. Selain itu, guru kelas juga mengintegrasikan nilai karakter semangat kebangsaan melalui kegiatan di luar kelas. Pelaksanaan pembelajaran yang diintegrasikan dengan 
nilai karakter semangat kebangsaan dengan mengembangkan indikator dalam RPP. Dengan merinci Kompetensi Inti (KI) dan Kompetensi Dasar (KD) yang harus dikuasai oleh peserta didik. Kegiatan penanaman nilai karakter semangat kebangsaan juga memiliki serangkaian kegiatan di luar kelas ataupun di luar sekolah. Standar pengukuran yang digunakan oleh sekolah yaitu melalui penilaian sikap yang sudah tertuang dan dirinci melalui RPP. Penilaian ini tidak hanya mencakup penilaian pembelajaran di dalam kelas namun juga di luar kelas. Selama proses pelaksanaan nilai karakter semangat kebangsaan yang sudah dilakukan sekolah tentunya sudah terlihat perubahan yang ada pada sikap dan perilaku peserta didik. Perubahanperubahan tersebut juga memperlihatkan kemampuan peserta didik dalam menyikapi adanya perbedaan. Peserta didik memiliki sikap toleransi antara sesama teman dalam berbagai hal. Tentunya tidak semua peserta didik berubah secara drastis, namun lambat laun sekolah terus menerus memperbaiki sehingga seluruh peserta didik memiliki karakter semangat kebangsaan untuk melindungi, menjaga ketahanan, dan kedamaian bangsa dan negaranya singkatnya peserta didik menjadi warga negara yang baik.

\section{DAFTAR PUSTAKA}

Adha, M. A., Gordisona, S., Ulfatin, N., \& Supriyanto, A. (2019). Analisis Komparasi Sistem Pendidikan Indonesia dan Finlandia. Jurnal Studi Manajemen Pendidikan, 3(2), 145160.

https://doi.org/http://dx.doi.org/10.29 240/jsmp.v3i2.110

Ahmad, S. D. (2018). Finding Indonesian National Leaders Based On Pancasila ' $S$ Character The Member of Indonesian Parliament ( Dewan Perwakilan Rakyat Republik Indonesia ). Journal of Social Sciences and Humanities Invention, 5(09), 4969-4973. https://doi.org/10.18535/ijsshi/v5i9.0 2

Amir, S. (2013). Pancasila as Integration Philosophy of Education And National Character. International Journal of Scientific and Technology Research, 2(1), 54-57.

Andriani, G. (2014). Peningkatan Budaya Mutu untuk Pencapaian Akreditasi di Sekolah Dasar Widoro Yogyakarta.

Arifin, I., Juharyanto, Mustiningsih, \& Taufiq, A. (2018). Islamic Crash Course as a Leadership Strategy of School Principals in Strengthening School Organizational Culture. SAGE Open, $8(3), \quad 1-10$. https://doi.org/10.1177/21582440187 99849

Ash-shidiqqi, E. A. (2018). The Analysis of Character Education in Indonesia. International Journal of Humanities, Art and Social Studies (IJHAS), 3(4), 39-46.

Asmani. (2012). Tips Menjadi Kepala Sekolah Profesional. Diva Press.

Bafadal, I. (2015). Penumbuhan Budi Pekerti Peserta Didik. Prosiding Seminar Nasional Pendidikan Jurusan Administrasi Pendidikan Universitas Negeri Malang.

http://ap.fip.um.ac.id/wpcontent/uploads/2017/03/13-IbrahimBafadal.pdf

Borsheim, C., Merritt, K., \& Reed, D. (2008). Beyond Technology for Technology's Sake: Advancing Multiliteracies in the Twenty-First Century" dalam The Clearing House November-Desember. The Clearing House: A Journal of Educational Strategies, Issues and Ideas, 82(2), 87-90.

https://doi.org/https://doi.org/10.3200 /TCHS.82.2.87-90

Dubihlela, J., \& Sandada, M. (2014). Impact of strategic planning on small and medium-sized Enterprises (SMEs) Performance: The role of employee participation, implementation incentives and evaluation and control. 
Journal of Economics, 5(1), 45-55.

Fadlilatun. (2016). Penanaman Karakter Semangat Kebangsaan Di Sd Unggulan Aisyiyah Bantul. Jurnal Pendidikan Guru Sekolah Dasar, 11, 1033-1039.

Fadlillah, M. (2012). Desain Pembelajaran PAUD: Tinjauan Teoritik dan Praktik. Ar-Ruzz Media.

Fathoni, A. (2015). Pembelajaran Berbasis

Karakter. Universitas

Muhammadiyah Surakarta.

Febriyanti, T. (2017). Upaya Meningkatkan

Semangat Kebangsaan dan Prestasi

Belajar Melalui Model Value Clarification Technique (VCT) Dengan Permainan Acak Huruf Di Kelas V SD Negeri Ajibarang Kulon. Gunawan, H. (2012). Pendidikan Karakter: Konsep dan Implementasi. Alfabeta.

Hamalik, O. (2011). Proses Belajar Mengajar. Bumi Aksara.

Hayudiyani, M., Saputra, B. R., Adha, M. A., \& Ariyanti, N. S. (2020). Strategi Kepala Sekolah Meningkatkan Mutu Pendidikan melalui Program Unggulan Sekolah. Jurnal Akuntabilitas Manajemen Pendidikan, 8(1), 111-118.

Indratmoko, A., Ahmadi, K., \& Yunianto, C. (2019). Revitalisasi Pembangunan Karakter dalam Manajemen Pembelajaran Pendidikan Kewarnegaraan. Citizenship Jurnal Pancasila Dan Kewarganegaraan, 7(1), 18-27.

Jianfei, H. U., Xiuyun, W., Di, W., \& Chaoqian, T. (2017). The Influence and Enlightenment of the Media on National Spirit. Canadian Social Science, 13(8), 13-18. https://doi.org/10.3968/9843

Juharyanto, Bafadal, I., Arifin, I., Saputra, B. R., \& Adha, M. A. (2020). The Use of Conventional Communication Technology as an Effective Principal Leadership Strategy in Strengthening the Role of Multi-Stakeholder's Forum for School Quality Improvement. Elementary Education
Online, 19(4), 1963-1973. https://doi.org/10.17051/ilkonline.202 0.762773

Kalimantara, B. R. F. (2016). Manajemen Quality Assurance Sebagai Upaya Meningkatkan Kepercayaan Masyarakat Terhadap Sekolah. Manajemen Dan Supervisi Pendidikan, 1(1).

Kurniadin, D., \& Machali, I. (2012). Manajemen Pendidikan (Konsep dan Prinsip Pengelolaan Pendidikan. ArRuzz Media.

Lawrence, A. A., \& Lee, O. L. (2010). Pengantar Manajemen. Salemba Empat.

Lestyarini, B. (2012). Penumbuhan Semangat Kebangsaan Untuk Memperkuat Karakter Indonesia Melalui Pembelajaran Bahasa. Jurnal Pendidikan Karakter, 3, 341-354.

Lo, J. H. Y., Fu, G., Lee, K., \& Cameron, C. A. (2019). Development of Moral Reasoning in Situational and Cultural Contexts. Journal of Moral Education, 49(2), 177-193. https://doi.org/10.1080/03057240.201 8.1563881

Lusty, \& Maisyaroh. (2015). Peran Warga Sekolah Dalam Penerapan Pendidikan Lingkungan Hidup. Ilmu Pendidikan, 23(5), 454-459.

Maftei, A., \& Holman, A. (2019). Representation of Morality in Children: A Qualitative Approach. Journal of Moral Education, 49(2), 194-208.

https://doi.org/10.1080/03057240.201 9.1619542

Mustiningsih. (2017). The Implementation Of Curriculum Management And School-Based Learning In Indonesian Elementary School. Journal of Social Sciences (COES\&RJ-JSS), 6(4), 744761.

https://doi.org/10.25255/jss.2017.6.4. 744.761

Novitawati, Ulfatin, N., Arifin, I., \& Aslamiah. (2019). Religious scientific learning based on sentra in school. 
International Journal of Innovation, Creativity and Change, 5(5), 190-203.

Pane, M. M., \& Patriana, R. (2016). The Significance of Environmental Contents in Character Education for Quality of Life. Procedia - Social and Behavioral Sciences, 222, 244-252. https://doi.org/10.1016/j.sbspro.2016. 05.153

Parker, L. (2014). Religious Education for Peaceful Coexistence in Indonesia? South East Asia Research, 22(4), 487504.

https://doi.org/10.5367/sear.2014.023 1

Parker, L., \& Raihani, R. (2011). Democratizing Indonesia through Education? Community Participation in Islamic Schooling. Educational Management Administration \& Leadership, 39(6), 712-732. https://doi.org/10.1177/17411432114 16389

Priyambodo, A. B. (2017). Implementasi Pendidikan Karakter Semangat Kebangsaan Dan Cinta Tanah Air Pada Sekolah Berlatar Belakang Islam Di Kota Pasuruan. Jurnal Sains Psikolog, 6(1), 9-15.

Raihani. (2011). A Whole-School Approach: A Proposal for Education for Tolerance in Indonesia. Theory and Research in Education, 9(1), 2339.

https://doi.org/10.1177/14778785103 94806

Rokhman, F., Hum, M., \& Syaifudin, A. (2014). Character Education For Golden Generation 2045 ( National Character Building for Indonesian Golden Years ). Procedia - Social and Behavioral Sciences, 141, 1161-1165. https://doi.org/10.1016/j.sbspro.2014. 05.197

Samani. (2011). Konsep dan Model Pendidikan Karakter. PT Remaja Rosdakarya.

Saputri, D. I., \& Herwin. (2020). The Effect of The Spirit Of Nationalism and Cinta Tanah Air on The Self Independence of Elementary Schools Student. Journal of Madrasah Ibtidaiyah Education, 4(1), 114-126.

Sarah, S. (2015). Penerapan Pembelajaran Environmental Learning Untuk Meningkatkan Kesadaran Siswa Menjaga Kebersihan Lingkungan Kelas Dalam Pelajaran IPS. Universitas Pendidikan Indonesia.

Shidiq, A. F., \& Raharjo, S. T. (2018). Peran Pendidikan Karakter Di Masa Remaja Sebagai Pencegahan Kenakalan Remaja. Prosiding Penelitian Dan Pengabdian Kepada Masyarakat, $\quad 5(2), \quad 176$. https://doi.org/10.24198/jppm.v5i2.18 369

Sobry, M. S. (2012). Manajemen Pendidikan: Langkah Praktis Mewujudkan Lembaga Pendidikan yang Unggul. Holistica.

Soedjatmoko. (2009). Menjadi Bangsa Terdidik. Penerbit Buku Kompas.

Ulfatin, N. (2015). Metode Penelitian Kualitatif di Bidang Pendidikan: Teori dan Aplikasinya. Media Nusa Creative.

Ulfatin, N., Mukhadis, A., Maisyaroh, \& Sobri, A. Y. (2019). Indigenous Education in Indonesian-Traditional Families Migrant Workers abroad: From Mothering to Parenting and Schooling for Educational Design. International Journal of Innovation, Creativity and Change, 5(5), 244-255.

Wibowo, A. (2013). Manajemen Pendidikan Karakter Sekolah Konsep dan Praktik Implementasi. Pustaka Belajar.

Zahroh, A. (2016). Total Quality Management: Teori dan Prakttik Manajemen untuk Mendongkrak Mutu Pendidikan. Ar-Ruzz Media.

Zuchdi, D. (2009). Pendidikan Karakter: Grand Design dan Nilai-nilai Target. UNY Press.

Zulaikha, S. (2014). Implementasi Pendidikan Karakter dalam Pembelajaran. Jurnal Dinamika Ilmu, 14(2). 